Review

\title{
Magic year for multiple myeloma therapeutics: Key takeaways from the ASH 2015 annual meeting
}

\author{
Kejie Zhang ${ }^{1, *}$, Aakash Desai ${ }^{2,3, *}$, Dongfeng Zeng ${ }^{4}$, Tiejun Gong ${ }^{5}$, Peihua Lu$^{6}$ and \\ Michael Wang? \\ ${ }^{1}$ Department of Hematology, Zhongshan Hospital, Xiamen University, Fujian Medical University Clinic Teaching Hospital, \\ Xiamen, China \\ 2 Department of Lymphoma/Myeloma, The University of Texas MD Anderson Cancer Center, Houston, Texas, USA \\ ${ }^{3}$ University of Texas Health Science Center, Houston, Texas, USA \\ ${ }^{4}$ Department of Hematology, Xinqiao hospital, Third Military Medical University, Chongqing, China \\ ${ }^{5}$ Institute of Hematology and Oncology, Harbin first Hospital, Harbin, China \\ ${ }^{6}$ Department of Hematology, Hebei Yanda Ludaopei Hospital, Beijing, China \\ 7 Department of Lymphoma/Myeloma, The University of Texas MD Anderson Cancer Center, Houston, Texas, USA \\ * These authors have equal contribution to this work
}

Correspondence to: Michael Wang, email: miwang@mdanderson.org

Keywords: multiple myeloma, Ixazomib, elotuzumab, daratumumab

Received: March 25, $2016 \quad$ Accepted: October 19, $2016 \quad$ Published: November 11, 2016

\section{ABSTRACT}

Despite the availability of various anticancer agents, Multiple Myeloma (MM) remains incurable in most cases, along with high relapse rate in the patients treated with these agents. The year 2015 saw major advancements in our battle against multiple myeloma. In 2015, the U.S. Food and Drug Administration (FDA) approved three new therapies for multiple myeloma, namely Ixazomib (an oral proteasome inhibitor), Daratumumab and Elotuzumab (monoclonal antibodies against CD38 and SLAMF7 respectively). The purpose of this review is to provide a detailed analysis of these aforementioned breakthrough therapies and two other newer agents, Filanesib (kinesis spindle inhibitor) and selinexor (SINE inhibitor), presented at the 2015 annual meeting of American Society of Hematology (ASH). We also describe the role of agents targeting PD-1 axis and chimeric antigen receptor T (CAR-T) cells in the treatment of MM.

\section{INTRODUCTION}

The neoplastic proliferation of plasma cells that produce a monoclonal immunoglobulin is a characteristic of Multiple Myeloma (MM). MM is the $2^{\text {nd }}$ most common hematological malignancy after lymphomas and forms $10 \%$ of all hematological malignancies in the United States [1]. The American Cancer Society predicts that about 30,330 new MM cases and 12,650 deaths caused by $\mathrm{MM}$ are expected in the year 2016 [2]. Despite the improvement in 5 year survival rates for patients with MM from $25 \%$ between 1975 to 1977 to $43 \%$ between 2002 and 2008 [3], this disease still remains incurable using currently available therapies. With detailed understanding of the key signaling and regulatory pathways of the tumor and the tumor microenvironment, newer agents are being discovered and evaluated in clinical trials.
The year 2015 saw major advancements in our battle against MM. In 2015, the Food and Drug Administration (FDA) approved three new therapies for MM: an oral proteasome inhibitor, ixazomib; along with two monoclonal antibodies against CD38 and SLAMF7, daratumumab and elotuzumab, respectively. In this review, we provide a detailed analysis of these breakthrough therapies and presentations at the 2015 American Society of Hematology (ASH) meeting that will ultimately alter clinical practice in MM. We describe a newer generation reversible proteasome inhibitor (ixazomib), monoclonal antibody that recognizes SLAMF7 (elotuzumab) and CD38 (daratumumab), agents targeting the PD-1 axis and chimeric antigen receptor $\mathrm{T}$ (CAR-T) cells along with kinesis spindle inhibitor (Filanesib) and SINE inhibitor (selinexor). 
Table 1: Review and comparison of ixazomib, bortezomib, and carfilzomib

\begin{tabular}{|c|c|c|c|c|c|c|c|}
\hline $\begin{array}{l}\text { Genetic (brand) } \\
\text { name }\end{array}$ & Chemical structure & \begin{tabular}{|l|} 
Mechanism \\
of proteasome \\
inhibition
\end{tabular} & \begin{tabular}{|l|} 
Proteasome \\
dissociation \\
half-life $\left(\mathrm{t}_{1 / 2}\right)$
\end{tabular} & Administration & $\begin{array}{l}\text { Treatment } \\
\text { indication }\end{array}$ & \begin{tabular}{|l|} 
Incidence \\
of severe \\
PN
\end{tabular} & $\begin{array}{l}\text { US FDA } \\
\text { approval }\end{array}$ \\
\hline Bortezomib (Velcade) & & \begin{tabular}{|l|} 
Inhibits \\
caspase-like \\
and $(\beta 2)$ trypsin- \\
like sites of $20 \mathrm{~S}$ \\
proteasome, but \\
preferentially \\
inhibits \\
chymotrypsin-like \\
site
\end{tabular} & \begin{tabular}{|l|} 
Slowly \\
reversible $\beta 5$ \\
subunit: 110 \\
minutes
\end{tabular} & $\mathrm{iv} / \mathrm{sc}$ & $\begin{array}{l}\text { First line or } \\
\text { relapsed/ } \\
\text { refractory }\end{array}$ & High & 2003 \\
\hline Ixazomib (Ninlaro) & & $\begin{array}{|lr|}\text { Inhibits } & (\beta 1) \\
\text { caspase-like and } \\
(\beta 2) \quad \text { trypsin- } \\
\text { like sites of } 20 \mathrm{~S} \\
\text { proteasome, but } \\
\text { preferentially } \\
\text { inhibits } \\
\text { chymotrypsin-like } \\
\text { site }\end{array}$ & $\begin{array}{l}\text { Reversible } \\
\beta 5 \text { subunit: } \\
18 \text { minutes }\end{array}$ & Oral & $\begin{array}{l}\text { Relapsed/ } \\
\text { refractory }\end{array}$ & Low & 2015 \\
\hline Carfilzomib (Kyprolis) & & $\begin{array}{l}\text { Inhibits }(\beta 1) \\
\text { caspase-like and } \\
(\beta 2) \quad \text { trypsin- } \\
\text { like sites of } 20 \mathrm{~S} \\
\text { proteasome, but } \\
\text { preferentially } \\
\text { inhibits } \\
\begin{array}{l}\text { chymotrypsin-like } \\
\text { site }\end{array}\end{array}$ & Irreversible & iv & $\begin{array}{l}\text { Relapsed/ } \\
\text { refractory }\end{array}$ & Moderate & 2012 \\
\hline
\end{tabular}

Abbreviations: PI, proteasome inhibitor; iv, intravenous; sc, subcutaneous; PN, peripheral neuropathy; FDA, Food and Drug Administration

\section{NEW GENERATION ORAL REVERSIBLE PROTEASOME INHIBITOR}

With the advent of proteasome inhibitors (PIs), the survival of an average MM patient was prolonged [4]. Bortezomib, the first PI initially approved for use in relapsed/refractory MM patients, was later extended as a first-in-line treatment of newly diagnosed MM patients [5]; however, numerous limitations complicate bortezomib treatment. Firstly, bortezomib can cause peripheral neuropathy $(\mathrm{PN})$ in $37-44 \%$ of the MM patients. Also, its effectiveness is not universal as some patients are unresponsive, and the responders eventually relapse [6].

Carfilzomib is a second generation proteasome inhibitor (PI) that offers clinical advantage to several patients who relapse on bortezomib treatment. Also, this drug has a decreased incidence of PN [7]. However, drug resistance has been observed with carfilzomib treatment [7]. An important limitation to the use of both bortezomib and carfilzomib is that they have to be administered intravenously (iv), necessitating the administration of these drugs in a clinical setting, which may hamper patient's quality of life and increases the cost of treatment [8]. However, bortezomib is now available in subcutaneous forms, which causes less peripheral neuropathic side effects.

Ixazomib (Ninlaro ${ }^{\circledR}$ ), a newer generation reversible PI has clinical advantages compared with other PIs. Ixazomib acts on the $26 \mathrm{~S}$ proteasome and inhibits the $20 \mathrm{~S}$ catalytic subunit. At low concentrations, it reversibly inhibits the chymotrypsin-like activity of beta 5 subunit of the $20 \mathrm{~S}$ proteasome. At high concentrations, it inhibits the caspase-like activity of beta 1 subunit and trypsin-like activity of beta 2 subunit [9] (Table 1).

While both bortezomib and carfilzomib are given as injectable preparations, ixazomib is a novel orally administered PI approved by FDA in 2015 for use along with dexamethasone and lenalidomide for patients who were treated previously with at least one therapy. Its approval was based on the results of a randomized phase 3 TOURMALINE-MM1 study comparing treatment with ixazomib in combination with lenalidomide and dexamethasone (IRd) to treatment with lenalidomide and dexamethasone (Rd) alone. The results of which were presented at the 2015 ASH meeting [10]. Participants in the trial received one to three prior treatments. Patients refractory to previous PI- or lenalidomide-based treatment were excluded from the study. The IRd arm showed a greater progression free survival (PFS) compared to the $\mathrm{Rd}$ arm (20.6 months versus 14.7 months, $\mathrm{p}=0.012)$. The median overall survival (OS) was not reached in either arm. The median PFS in patients with unfavorable del (17) was similar to all other IRd-treated patients, suggesting that ixazomib may have a favorable effect in patients with genetic mutations. The reported side effects included rash, thrombocytopenia, leukopenia, nausea, diarrhea and fatigue, along with a few cases of PN. Given the favorable toxicity profile [11] and good manageability, the results of this orally administered chemo-free regimen are highly encouraging. The drug is being tested further as a frontline therapy, either with cyclophosphamide and dexamethasone 
(ICD-300 or ICD-400) or with lenalidomide and dexamethasone (TOURMALINE-MM2 study). The ORR in the study with ICD-300 and ICD-400 were 80 and $73 \%$, respectively [12]. Currently, Ixazomib is only approved for use along with lenalidomide and dexamethasone. However, ixazomib is under testing for use as a single agent maintenance therapy in patients after autologous stem cell transplant (ASCT) and in those who have not received ASCT [9]. Thrombocytopenia was reported for ixazomib in $31 \%$ of the patients undergoing treatment [10]. Non hematologic adverse events associated with ixazomib include gastrointestinal events and rash [13].

\section{MONOCLONAL ANTIBODIES - A NEW ERA IN THE TREATMENT OF MULTIPLE MYELOMA}

There has been a significant improvement in the survival rate of MM patients in the last 10 years [14]. Despite this progress, the median OS of patients refractory to both immunomodulatory drugs (IMiDs) and PIs is only 9 months $[15,16]$. Thus, an urgent need exists for newer agents with novel mechanisms of action $[17,18]$. Monoclonal antibodies (mAbs) are novel agents that

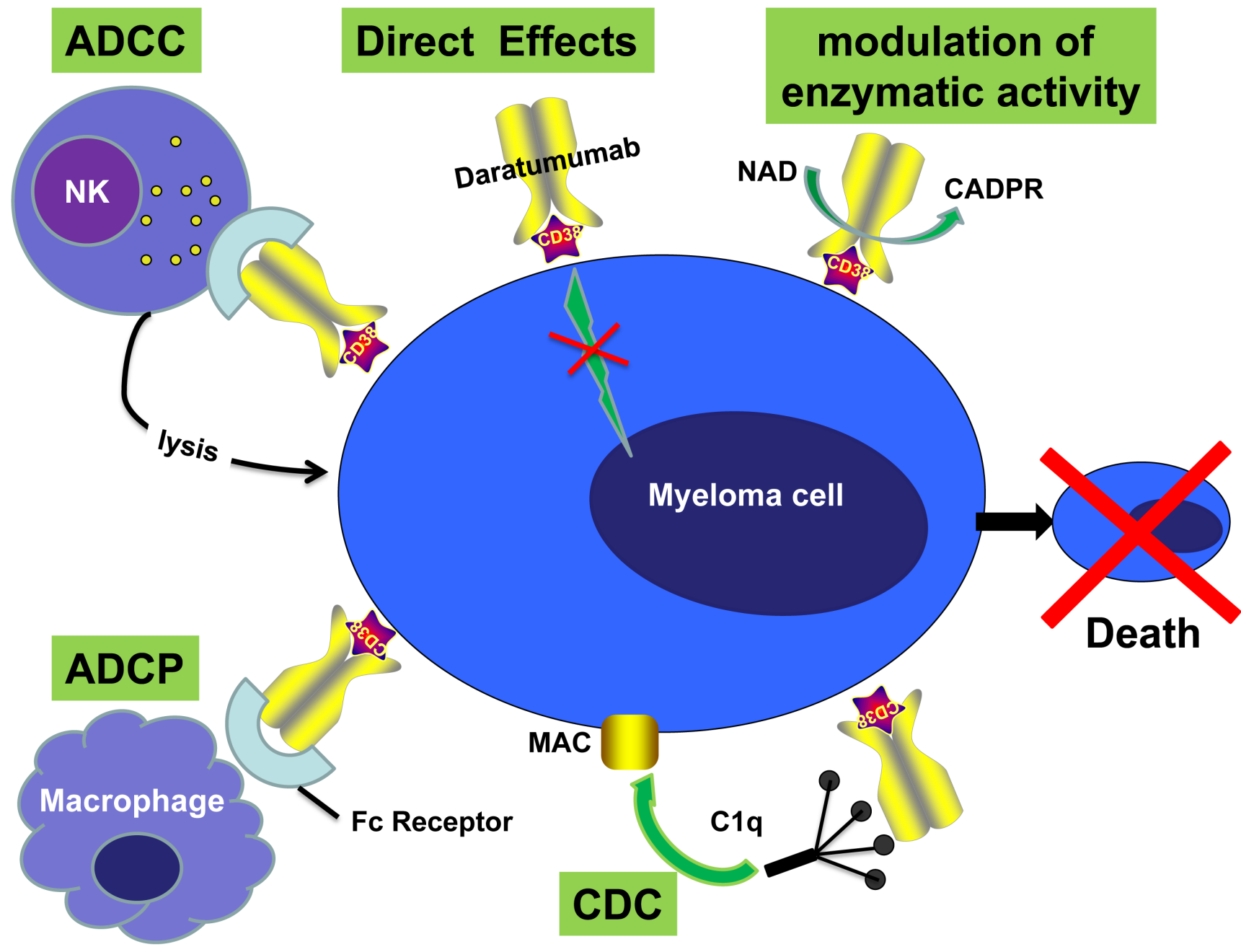

Figure 1: Mechanisms of action of monoclonal antibody (Daratumumab) targeting surface CD38 antigen on MM cells. Daratumumab against CD38 antigen can induce tumor cell killing via Fc-dependent effector mechanisms including CDC, ADCC, and ADCP. The process of ADCC is achieved through activation of Fc receptors on myeloid and NK effector cells by tumor cell-attached immunoglobins. Subsequent cytotoxicity is mediated through $\geq 2$ different mechanisms; one involving the release of perforin and granzymes from effector cells and the other involving death ligands FasL and tumor necrosis factor-related apoptosis-inducing ligand. In ADCP, phagocytosis of tumor cells is mediated by macrophages. CDC is dependent on the interaction of the antibody Fc domains with the classic complement-activating protein $\mathrm{Clq}$ leading to activation of downstream complement proteins, which results in the assembly of the membrane attack complex (MAC), that punches holes in the tumor cells. An additional result of this cascade is the production of chemotactic complement molecules C3a and C5a, which recruit and activate immune effector cells. There is also evidence that uptake of antibody-opsonized tumor cells and cellular fragments by antigen-presenting cells is associated with enhanced antigen presentation leading to tumor-specific T-cell responses. Daratumumab may also have direct effects via modulation of the activity of the targeted antigen and modulation of enzymatic activity. 
have shown promising results in recent MM clinical trials [19], $[20,21]$. In the current review, we will specifically focus on the monoclonal antibodies: daratumumab and elotuzumab.

\section{Daratumumab: Anti-CD38 monoclonal antibody}

CD38 (Cluster of differentiation 38) is responsible for cellular adhesion, signal transduction and calcium signaling. CD38 expression on plasma cells is higher as compared to other hematological and solid tissues. Plasma cell tumors such as MM highly express CD38, which led to the development of therapeutic anti- CD38 antibodies [22].

Daratumumab (Darzalex), an IgG1 kappa human monoclonal antibody directed against CD38 antigen, is the first monoclonal antibody approved for use in MM. Antibody-dependent cellular cytotoxicity (ADCC), complement-dependent cytotoxicity (CDC), antibodydependent cellular phagocytosis (ADCP), apoptosis induction via FcR-mediated crosslinking or caspasedependent MM cell death, modulation of enzymatic activity, and immunomodulatory activity are the various mechanisms of action for Daratumumab [23-26] (Figure 1). In a phase II trial, single agent daratumumab showed approximately $30 \%$ response rate in heavily pretreated MM patients [27]. In 2015, Daratumumab, was approved by the FDA [28] to treat patients with MM who had received at least 3 prior therapies including either a PI or an IMiD, or those who are double-refractory to these drugs.

At the 2015 ASH meeting, researchers reported results of a phase 1/2 study (GEN503) of Darzalex in combination with dexamethasone and lenalidomide in patients who had relapsed or refractory (R/R) MM [29]. After 7.8 months of median follow up, an $88 \%$ ORR was recorded. The PFS and OS were not achieved. The type and rate of infusion-related reactions were similar to those reported in studies of Darzalex monotherapy. Toxicity was common but was not increased as compared to that caused by lenalidomide/dexamethasone. The combined analysis of the GEN501 and SIRIUS trials that studied

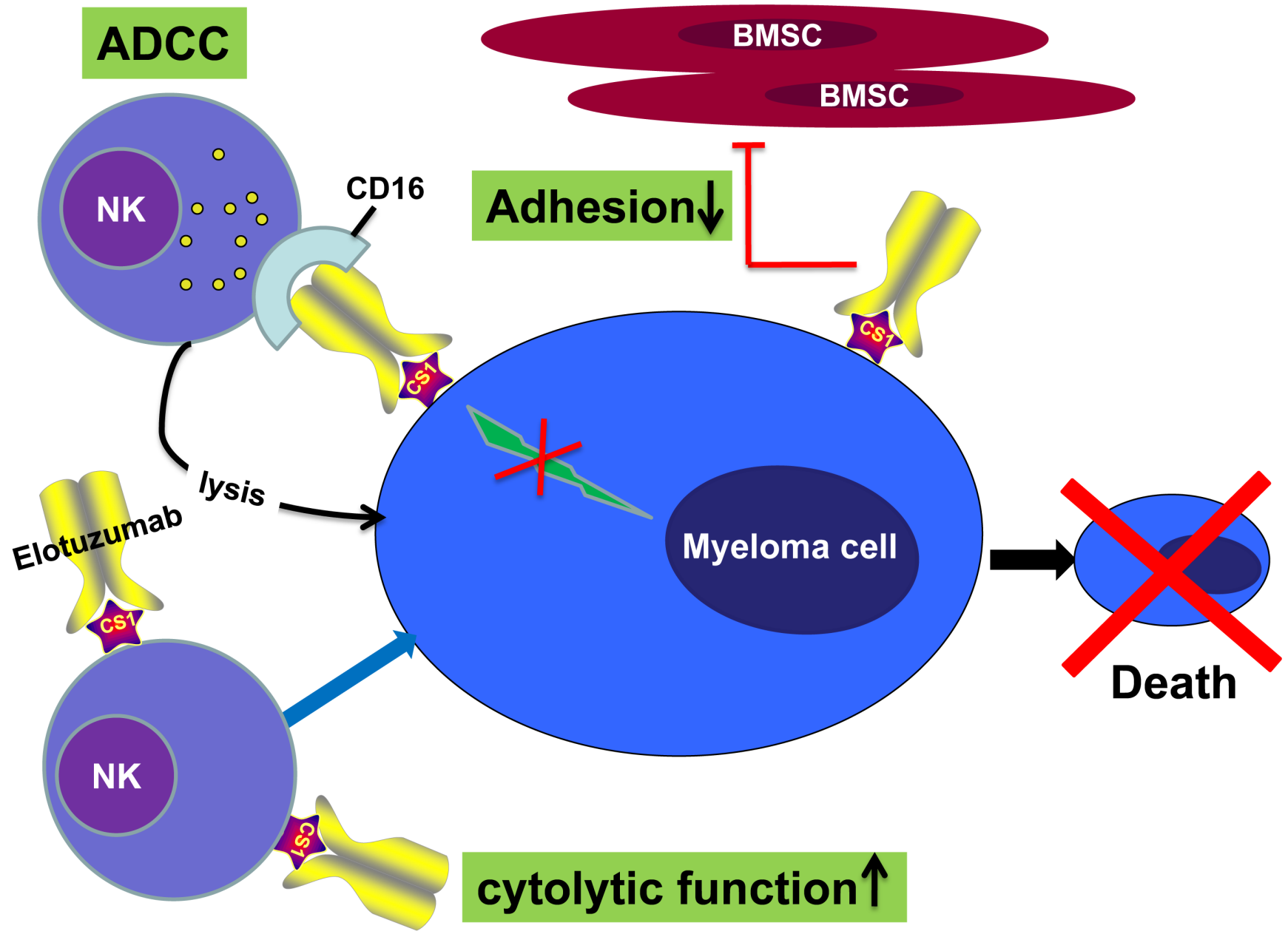

Figure 2: Mechanisms of action of elotuzumab. The primary mechanism of action of elotuzumab against myeloma cells is NK cellmediated ADCC. Elotuzumab can also interfere with the adhesion of myeloma cells to bone marrow stromal cells (BMSC), or can induce NK cell activation directly through binding CS1 expressed on NK cells. 
daratumumab as a monotherapy in R/R MM (relapsed or refractory multiple myeloma) created much interest [30]. Despite the ORR being 31\%, a median OS of 20.1 months was reported on the combined analysis of the two trials. The median OS was not reached among the responders, while in those with minimal or no response, OS was reported to be 17.5 months, which favorably compared with historical controls. Another open label, multicenter study of Darzalex investigated the drug in combination with Pomalyst (pomalidomide, Imnovid) and dexamethasone in R/R MM patients with at least two lines of prior therapy [31]. The ORR was $58.5 \%$, including a $57.5 \%$ response rate in patients who were doublerefractory to a PI and an IMiD. After a median followup of 4.2 months, the six-month estimated PFS was $66 \%$, and no additional safety concerns were noted. The most common hematological side effects of any grade $(\geq 20 \%)$ were anemia, thrombocytopenia, and neutropenia [27, 31].

\section{Elotuzumab: Anti-CS1 monoclonal antibody}

CS1 (cell-surface glycoprotein CD2 subset 1), also known as SLAMF7, is a cell surface glycoprotein receptor located on chromosome 1q23 [32]. SLAMF7 expression is high in myeloma cells and natural killer (NK) cells but not on normal tissues, making CS1 a potential target for MM immunotherapies [33].

Elotuzumab (Empliciti ${ }^{\text {TM}}$ ) is a humanized immunoglobulin (Ig) G1-k monoclonal antibody targeting CS1. NK cell-mediated ADCC through the CD 16 pathway is the predominant elotuzumab mechanism of action [33]. Elotuzumab activates natural killer cells through Fc receptors and the SLAMF7 pathway. After binding to CS1, elotuzumab binds to CD16 on NK cells, activating the NK cell and leading to release of cytotoxic granules, eventually leading to MM cell death [34]. CS1 activates NK cells by coupling with EWS/FLI1 Activated Transcript 2 (EAT-2). In MM cells, CS1 signaling is compromised due to absence of EAT-2 expression; thus, it does not affect the proliferation of MM cells [35, 36]. Elotuzumab also impairs adhesion of MM cells to bone marrow stromal cells (BMSCs) [37](Figure 2).

Elotuzumab lacks single-agent activity, unlike the anti-CD38 antibodies. However, this antibody has synergistic activity when combined with dexamethasone

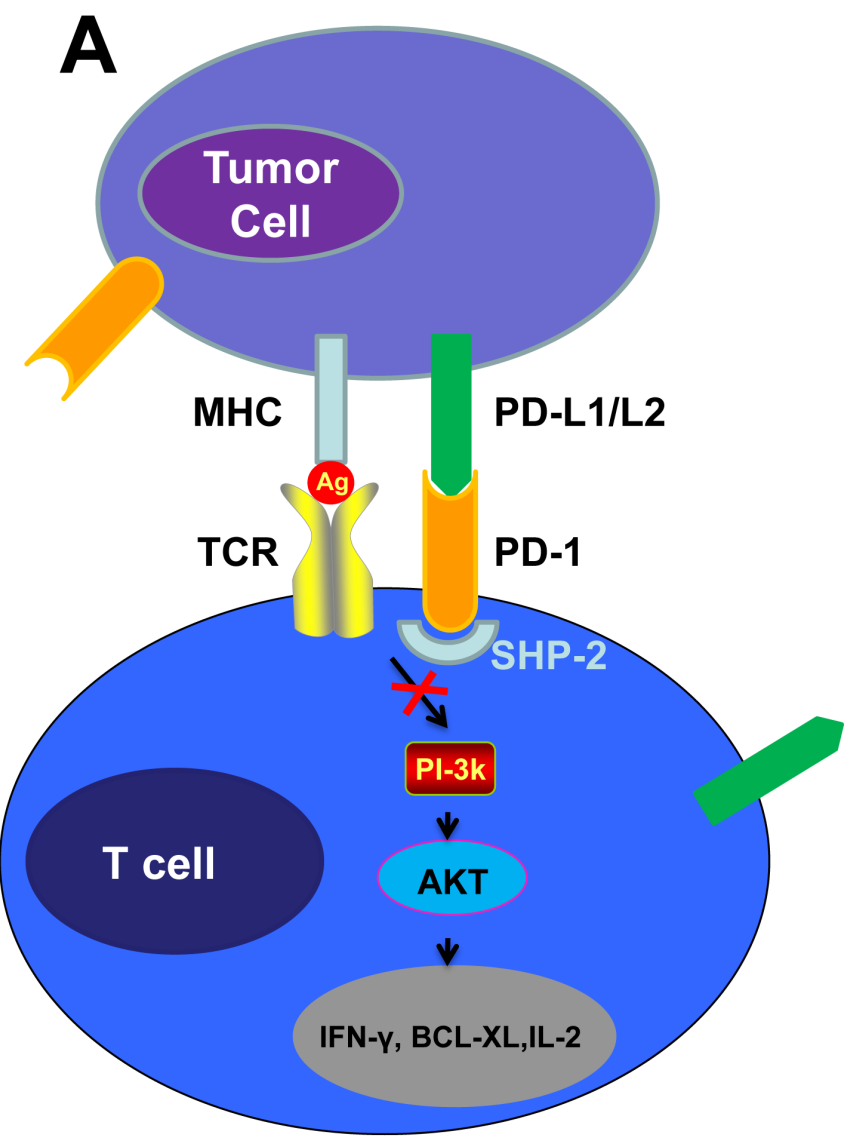

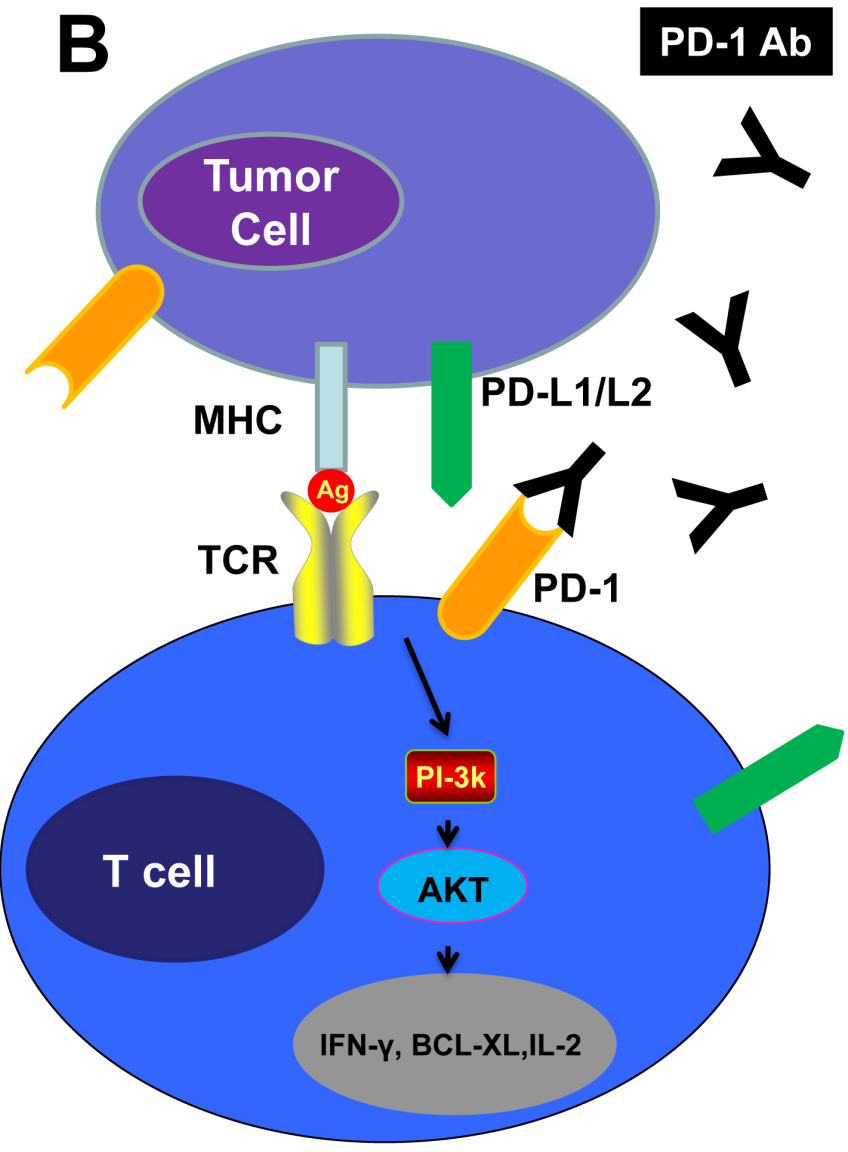

Figure 3: Checkpoint Inhibition via the PD-1 Pathway "Put the Brakes on" the Antitumor Response, While PD-1 or PD-1-Blocking Antibodies Release the Brakes. A, PD-L1 expressed on tumor cells binds to PD-1 on T-cells recruiting a phosphatase, SHP-2, which blocks the PI3K pathway and leads to down-regulation of T-cell survival proteins, including IFN- $\gamma$, BCL-XL and IL-2, resulting in T-cell anergy or "exhaustion", thereby "braking" the T-cell immune response. B, The anti-PD-1 antibodies block the PD-1 pathway "release the brake" preventing suppression of the anti-tumor response. 
plus lenalidomide ( $\mathrm{Rd}$ ) [38]. The combination of elotuzumab with $\mathrm{Rd}$ showed a 30\% risk reduction for disease progression and death in patients with $\mathrm{R} / \mathrm{R} \mathrm{MM}$. These interim results of a landmark ELOQUENT-2 phase 3 trial, presented at ASCO 2015, are the largest analysis of a monoclonal antibody in MM and the first positive findings for a targeted immunotherapy approach in a phase 3 clinical trial in patients with MM. Based on this study, elotuzumab was declared a breakthrough therapy by the U.S. FDA for patients who have received $\geq 1$ previous therapies for MM [39].

At the ASH meeting, updated data provided longer follow-up results of the ELOQUENT-2 phase 3 trial [40]. Previously, at a median follow-up of 24 months, the PFS rates were $41 \%$ in the triple-therapy arm of ERd and $27 \% \mathrm{Rd}$ alone $(P=.004)$. At 1 year, the PFS rates were $68 \%$ and $57 \%$, respectively. The OS rates were $79 \%$ and $66 \%(P=.002)$, respectively. In the ASH update, the 3 -year PFS rates were $26 \%$ and $18 \%$ in the two arms, respectively. A time-to-next-treatment analysis favored the Empliciti arm (33 months versus 23 months). Interim OS analysis showed a trend in favor of ERd. Furthermore, a phase 2 randomized study of lenalidomide and dexamethasone combined with elotuzumab versus lenalidomide and dexamethasone without elotuzumab showed promising results as well [41].The median PFS figures were 9.9 months versus 6.8 months. The two-year follow-up showed a $24 \%$ reduction in the risk of disease progression, and OS analysis showed a $25 \%$ reduction in the risk of death, with no significant increases in adverse events. However, being a phase 2 study, the trial was not powered to assess the true benefit of elotuzumab in combination with lenalidomide and dexamethasone. Of note, elotuzumab activity against disease with high risk cytogenetic features such as $t(4 ; 14)$ and del $(17 p)$ has been reported [42]. These patients typically have less benefit from conventional therapies. The common adverse events for elotuzumab are hematological adverse events. In Lonial et al's study $34 \%$ of patients had neutropenia (grade 3/4) in elotuzumab group versus $44 \%$ in the control group; lymphocytopenia (grade 3/4) was reported in $77 \%$ and $49 \%$ of patients, respectively [42].

Up until this point, we have analyzed the three MM therapies newly approved by the U.S. FDA. The pivotal efficacy results and the main toxicities of these are shown in Table 2.

\section{IMMUNE CHECKPOINT INHIBITORS TARGETING PD-1/PD-L1 AXIS}

A member of the B7 receptor family, Programmed Death-1 (PD-1), has a significant role in immune regulation. The PD-1 receptor is a member of the immunoglobulin superfamily and is a 288-amino acid type I transmembrane protein [43, 44]. PD-1 is upregulated on activated macrophages, B cells, T cells, NK cells, NKT cells, and dendritic cells (DCs) [43]. Binding of PD-1 to PD-L1 (B7-H1) and PD-L2 (B7-DC) ligands causes activated T-cell apoptosis via negative signaling [45]. The higher expression of SHP-2, a cytoplasmic SH2 domain containing protein tyrosine phosphatase, causes the inhibition of the PI3K pathway and the subsequent inhibition of AKT. This results in a decreased production of Bcl-xL, a molecule associated with the intrinsic apoptotic pathway [43] (Figure 3). The end result of the PD-1 pathway is immune tolerance [46]. Cancer cells utilize the PD-1 pathway through expression of PD-L1 on tumor-infiltrating lymphocytes (TILs) [47] leading to impairment of anti-tumor responses [48]. Thus, antibodies targeting the PD-1 axis "release the brakes" on T-effectors causing anti-tumor cytotoxicity [49]. The presence of PD-1 on T-regulatory $\left(\mathrm{T}_{\text {reg }}\right)$, B- and NK-cells enhances anti-tumor cytotoxicity through increased NK cellmediated killing and $\mathrm{T}_{\text {reg }}$ suppression via PD-1 blockade $[50,51]$.

Currently, the use of anti PD-1 agents is a "hot topic" in cancer therapeutics. Two widely marketed anti PD-1 agents, pembrolizumab and nivolumab (IgG4 isotype antibodies), have both been approved in squamous non-small-cell lung cancer and melanoma. PD-1 blockade as a treatment option in MM has been investigated in various clinical trials, with disappointing results in general [52]. 27 patients with $\mathrm{R} / \mathrm{R}$ MM were enrolled in an active phase I trial of nivolumab in hematologic malignancies. The preliminary results of the trial were reported at the 2014 ASH Annual Meeting [53]. Although no objective response was observed in this study, 18 patients $(67 \%)$ had stable disease, and the PFS at 24 weeks was $15 \%$.

At the 2015 ASH meeting, pembrolizumab (KEYTRUDA) showed a much more robust response when combined with immune-modulatory drugs. Pembrolizumab was tested as a combination therapy with lenalidomide and dexamethasone for patients with $R / R$ $\mathrm{MM}$ in the KEYNOTE-023 phase 1 trial [54]. An ORR of $76 \%$ was observed with a recommended fixed dose of $200 \mathrm{mg}$. In another study presented at the ASH meeting, Pembroluzimab was combined with pomalidomide and dexamethasone in patients with $\mathrm{R} / \mathrm{R} \mathrm{MM}$ [55]. The trial enrolled 33 patients, of whom $23(70 \%)$ were refractory to an immunomodulatory drug and a proteasome inhibitor. An ORR of $60 \%$ in 27 evaluable patients was observed. The response rate was $55 \%$ in 20 patients who were refractory to both IMiD and PI.

\section{CHIMERIC ANTIGEN RECEPTOR (CAR) T- CELL THERAPY}

Single CAR T-cell therapy is a massive advancement in the development of immune therapy against cancers. CAR T-cells, developed to express the 
Table 2: Selected studies with ixazomib, elotuzumab and daratumumab in relapsed/refractory MM

\begin{tabular}{|c|c|c|c|c|c|c|c|c|}
\hline Study & $\begin{array}{l}\text { Type of } \\
\text { study }\end{array}$ & Regimen & Schedule & $\mathbf{N}$ & Prior treatment & Response & TTE & Key toxicities \\
\hline $\begin{array}{l}\text { TOURMALINE-MM1 } \\
\text { Moreau P, } \\
\text { et al8 }\end{array}$ & Phase 3 & $\begin{array}{l}\text { Ixazomib } \\
\text { Revlimid } \\
\text { dexamethasone } \\
\text { vs } \\
\text { Revlimid } \\
\text { dexamethasone }\end{array}$ & $\begin{array}{l}\text { ixazomib } \\
4 \mathrm{mg}, \mathrm{PO} \mathrm{d} 1,8,15 \\
\text { lenalidomide } \\
25 \mathrm{mg} \text { PO d } 1-21 \\
\text { dexamethasone } \\
40 \mathrm{mg} \text { PO d } 1,8,15,22, \\
\text { In } 28 \text { d cycles }\end{array}$ & 722 & $\begin{array}{l}\text { RRMM } \\
\text { after } 1-3 \text { prior lines of } \\
\text { therapy } \\
\text { bortezomib } 69 \% \\
\text { thalidomide } 45 \% \\
\text { lenalidomide } 12 \%\end{array}$ & 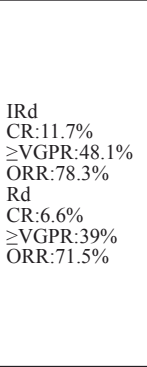 & $\begin{array}{l}\text { IRd } \\
\text { Median PFS: } \\
20.6 \text { mos., } \\
\text { OS: No results } \\
\text { provided } \\
\text { Rd } \\
\text { Median PFS: } \\
\text { 14.7 mos., } \\
\text { OS: No results } \\
\text { provided }\end{array}$ & 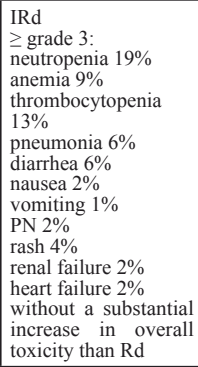 \\
\hline $\begin{array}{l}\text { NCT02046070 } \\
\text { Dimopoulos MA } \\
\text { et al10 }\end{array}$ & Phase 2 & $\begin{array}{l}\text { Ixazomib } \\
\text { Cyclophosphamideide } \\
\text { Dexamethasone }\end{array}$ & $\begin{array}{l}\text { ixazomib } \\
4 \mathrm{mg} \text { PO d } 1,8,15 \\
\text { cyclophosphamide } \\
300 \mathrm{mg} / \mathrm{m} 2 \text { (ICd-300 arm) } \\
400 \mathrm{mg} / \mathrm{m} 2 \text { (ICd-400 } \\
\text { arm) } \\
\text { PO d } 1,8,15 \\
\text { dexamethasone } \\
40 \mathrm{mg} \text { PO d } 1,8,15,22, \\
\text { In } 28 \text { d cycles }\end{array}$ & $\begin{array}{l}70 \\
\text { (Transplant- } \\
\text { Ineligible) }\end{array}$ & NDMM & $\begin{array}{l}\text { ICd-300 } \\
\text { CR: } 10 \% \\
\text { PR: } 70 \% \\
\text { VGPR: } 17 \% \\
\text { ORR: } 80 \% \\
\text { SD:6\% } \\
\text { ICd-400 } \\
\text { CR:3\% } \\
\text { PR: } 19 \% \\
\text { VGPR: } 4 \% \\
\text { ORR: } 7 \% \\
\text { SD: } 8 \%\end{array}$ & $\begin{array}{l}\text { No results } \\
\text { provided }\end{array}$ & 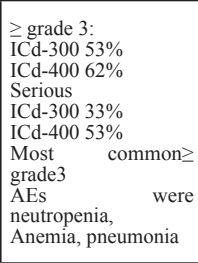 \\
\hline $\begin{array}{l}\text { ELOQUENT-2 } \\
\text { Dimopoulos MA, } \\
\text { et al32 } \\
\text { Lonial S, } \\
\text { et al34 }\end{array}$ & phase 3 & $\begin{array}{l}\text { elotuzumab } \\
\text { lenalidomide } \\
\text { dexamethasone } \\
\text { vs lenalidomide } \\
\text { dexamethasone }\end{array}$ & $\begin{array}{l}\text { Elotuzumab: iv } \\
10 \mathrm{mg} / \mathrm{kg} \mathrm{d} \mathrm{d} 1,8,15,22 \\
\text { for cycles } 1-2 \\
10 \mathrm{mg} / \mathrm{kg} \mathrm{d} 1,15, \\
\text { starting with cycles } 3 \\
\text { lenalidomide : PO } \\
25 \mathrm{mg} \mathrm{d} 1-21 \\
\text { dexamethasone: } \\
\text { weekly } \\
8 \mathrm{mg} \text { iv and } 28 \mathrm{mg} \text { po, on } \\
\text { elotuzumab days } \\
40 \mathrm{mg} \text { po on other days } \\
\text { In } 28 \mathrm{~d} \text { cycles } \\
\text { Len: } 25 \mathrm{mg} \text { on days } 1-21 \\
\text { Dex: } 40 \mathrm{mg} \text { once weekly } \\
\text { In } 28 \text { d cycles }\end{array}$ & 646 & $\begin{array}{l}\text { RRMM } \\
\text { Median: } 2 \\
\text { Range: } 1-4 \\
\text { thalidomide: } 48 \% \\
\text { lenalidomide (not } \\
\text { refractory): } 6 \% \\
\text { bortezomib: } 70 \%\end{array}$ & $\begin{array}{l}\text { >PR: } 79 \% \\
\text { VGPR: } 28 \% \\
\text { CR: } 4 \% \\
\text { >PR: } 66 \% \\
\text { VGGR: } 21 \% \\
\text { CR: } 7 \%\end{array}$ & $\begin{array}{l} \\
\text { Median PFS: } \\
19.4 \text { mos. } \\
\text { PFS at } 3 \text { years: } \\
26 \% \\
\text { OS at } 1 \text { year: } \\
79 \% \\
\text { Median PFS: } \\
14.9 \text { mos. } \\
\text { PFS at } 3 \text { years: } \\
18 \% \text { } \\
\text { OS at } 1 \text { year: } \\
66 \%\end{array}$ & $\begin{array}{l}\text { Grade } 3 / 4 \\
\text { lymphopenia: } 78 \% \\
\text { neutropenia: } 35 \% \\
\text { anemia: } 20 \% \\
\text { thrombocytopenia: } \\
21 \% \\
\text { Herpes zoster: } 4.1 \text { per } \\
100 \text { patient-years } \\
\text { Infections (any grade) } \\
: 83 \% \\
\text { IRR: } 10 \% \text { (mostly } \\
\text { grade } 1 / 2 \text { ) } \\
\text { Grade } 3 / 4 \\
\text { lymphopenia: } 49 \% \\
\text { neutropenia: } 44 \% \\
\text { anemia: } 21 \% \\
\text { thrombocytopenia: } \\
20 \% \\
\text { Herpes zoster: } 2.2 \text { per } \\
100 \text { patient-years } \\
\text { Infections (any grade) } \\
: 75 \%\end{array}$ \\
\hline $\begin{array}{l}\text { NCT01478048 } \\
\text { Palumbo A, } \\
\text { et al33 }\end{array}$ & phase 2 & $\begin{array}{l}\text { elotuzumab bortezomib } \\
\text { dexamethasone } \\
\text { vs bortezomib } \\
\text { dexamethasone }\end{array}$ & $\begin{array}{l} \\
\text { Elotuzumab: iv } \\
10 \mathrm{mg} / \mathrm{kg} \mathrm{d} 1,8,15,22 \\
\text { for cycles } 1-2 \\
10 \mathrm{mg} / \mathrm{kg} \mathrm{d} 1,11 \\
\text { for cycles } 3-8 \\
10 \mathrm{mg} / \mathrm{kg} \mathrm{d} 1,15 \\
\text { starting with cycles } 9 \\
\text { bortezomib : iv/ih } \\
1.3 \mathrm{mg} / \mathrm{m} 2 \mathrm{~d} 1,4,8,11 \\
\text { for cycles } 1-8 \\
1.3 \mathrm{mg} / \mathrm{m} 2 \mathrm{~d} 1,8,15 \\
\text { starting with cycles } 9 \\
\text { dexamethasone: } \\
8 \mathrm{mg} \text { iv and } 8 \mathrm{mg} \text { po, on } \\
\text { elotuzumab days } \\
20 \mathrm{mg} \text { po on other days } \\
\text { In } 21 \text {-day cycles for cycles } \\
1-8 \text { and then in } 28 \text {-day } \\
\text { cycles } \\
\text { bortezomib : iv/ih } \\
1.3 \mathrm{mg} / \mathrm{m} 2 \mathrm{~d} 1,4,8,11 \\
\text { for cycles } 1-8 \\
1.3 \mathrm{mg} / \mathrm{m} 2 \mathrm{~d} 1,8,15 \\
\text { starting with cycles } 9 \\
\text { dexamethasone: } 20 \mathrm{mg} \text { po } \\
\text { In } 21 \text {-day cycles for cycles } \\
1-8 \text { and then in } 28 \text {-day } \\
\text { cycles }\end{array}$ & 152 & $\begin{array}{l} \\
\text { RRMM } \\
\text { Median: } 1 \\
\text { Range: } 1-3 \\
\text { Prior IMiD: } 74 \% \\
\text { Prior PI (not } \\
\text { refractory): } 52\end{array}$ & $\begin{array}{l}\text { CR:4\% } \\
\text { VGPR:33\% } \\
\text { PR: } 30 \% \\
\text { ORR:66\% } \\
\text { MR:5\% } \\
\text { SD: } 17 \% \\
\text { PD:5\% } \\
\text { NE:7\% } \\
\text { CR:3\% } \\
\text { VGPR:23\% } \\
\text { PR: } 36 \% \\
\text { ORR: } 6 \% \\
\text { MR:7\% } \\
\text { SD: } 19 \% \\
\text { PD:5\% } \\
\text { NE: } 7 \%\end{array}$ & $\begin{array}{l} \\
\end{array}$ & $\begin{array}{l}\text { Any grade ( } \geq \text { grade } 3) \\
\text { All 100\% }(71 \%) \\
\text { Infection } 67 \%(21 \%) \\
\text { Diarrhea } 44 \%(8 \%) \\
\text { Constipation } 40 \% \\
(1 \%) \\
\text { Cough } 44 \%(1 \%) \\
\text { Anemia } 37 \%(7 \%) \\
\text { Peripheral neuropathy } \\
36 \%(9 \%) \\
\text { Pyrexia } 37 \%(0 \%) \\
\text { peripheral edema } \\
29 \%(4 \%) \\
\text { Insomnia } 29 \%(1 \%) \\
\text { Asthenia } 28 \%(4 \%) \\
\text { Fatigue } 29 \%(4 \%) \\
\text { Paresthesia } 27 \%(0 \%) \\
\text { Nausea } 27 \%(1 \%) \\
\text { thrombocytopenia } \\
16 \%(9 \%) \\
\text { IRR in elotuzumab } \\
\text { group: } 7 \%(\text { all grade } \\
1 / 2) ; \text { no additional } \\
\text { events in elotuzumab } \\
\text { group compared with } \\
\text { control group } \\
\text { All } 96 \%(60 \%) \\
\text { Infection } 53 \%(13 \%) \\
\text { Diarrhea } 33 \%(4 \%) \\
\text { Constipation } 29 \% \\
\text { (0\%) } \\
\text { Cough } 24 \%(0 \%) \\
\text { Anemia } 29 \%(7 \%) \\
\text { Peripheral neuropathy } \\
36 \%(12 \%) \\
\text { Pyrexia } 28 \%(4 \%) \\
\text { peripheral edema } \\
24 \%(0 \%) \\
\text { Insomnia } 19 \%(1 \%) \\
\text { Asthenia } 29 \%(3 \%) \\
\text { Fatigue } 25 \%(1 \%) \\
\text { Paresthesia } 19 \%(5 \%) \\
\text { Nausea } 21 \%(1 \%) \\
\text { thrombocytopenia } \\
27 \%(17 \%)\end{array}$ \\
\hline
\end{tabular}




\begin{tabular}{|c|c|c|c|c|c|c|c|c|}
\hline $\begin{array}{l}\text { SIRIUS } \\
\text { Lonial S, } \\
\text { et al22 }\end{array}$ & phase 2 & daratumumab & $\begin{array}{l}\text { Initially daratumumab } \\
8 \text { or } 16 \mathrm{mg} / \mathrm{kg} ; 16 \mathrm{mg} / \\
\mathrm{kg} \text { was established as the } \\
\text { recommended dose for } \\
\text { further study. } \\
\text { Daratumumab } 16 \mathrm{mg} / \mathrm{kg} \\
\text { was given weekly for } 8 \\
\text { weeks, every } 2 \text { weeks for } \\
16 \text { weeks, followed by } \\
\text { monthly infusions }\end{array}$ & $\begin{array}{l}\text { Daratumumab } \\
16 \mathrm{mg} / \mathrm{kg}: 106\end{array}$ & $\begin{array}{l}\text { RRMM } \\
\text { Daratumumab } 16 \mathrm{mg} / \\
\text { kg; } \\
\text { Median: } 5 \\
\text { Range: } 2-14 \\
\text { Thal: } 44 \% \\
\text { Len-refractory: } 88 \% \\
\text { Bort-refractory: } 90 \% \\
\text { Carf-refractory: } 48 \% \\
\text { Pom-refractory: } 63 \%\end{array}$ & 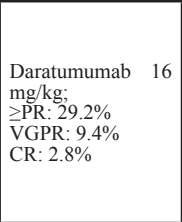 & $\begin{array}{l}\text { Daratumumab } \\
16 \mathrm{mg} / \mathrm{kg} ; \\
\text { Median PFS: } 3.7 \\
\text { mos. } \\
\text { OS at } 1 \text { year: } \\
64.8 \%\end{array}$ & $\begin{array}{l}\text { Daratumumab } \\
\mathrm{mg} / \mathrm{kg} ; \\
\text { Any grade } \\
\text { fatigue } 40 \% \\
\text { anemia } 33 \% \\
\text { IRR: } 43 \% ; \text { mostly } \\
\text { grade } \\
1 / 2 \text { (grade } 3 \text { in } 5 \% \text { ) }\end{array}$ \\
\hline $\begin{array}{l}\text { GEN503 } \\
\text { Plesner T, } \\
\text { et al24 }\end{array}$ & Phase 1/2 & $\begin{array}{l}\text { daratumumab } \\
\text { lenalidomide } \\
\text { dexamethasone }\end{array}$ & $\begin{array}{l}\text { MTD not reached; highest } \\
\text { dose-level: } \\
\text { Daratumumab } 16 \mathrm{mg} / \mathrm{kg} \text { iv } \\
\text { weekly for cycles } 1-2 \text {, } \\
\text { every other week for } \\
\text { cycles } 3-6 \\
\text { monthly starting with } \\
\text { cycle } 7 \\
\text { Len: } 25 \mathrm{mg} \text { po days } 1-21 \\
\text { Dex: } 40 \mathrm{mg} \text { weekly } \\
\text { In } 28 \text { d cycles }\end{array}$ & $\begin{array}{l}\text { Phase } 2 \text { with } \\
\text { daratumumab } \\
16 \mathrm{mg} / \mathrm{kg}: 32\end{array}$ & $\begin{array}{l}\text { RRMM } \\
\text { Phase } 2 \text { with } \\
\text { daratumumab } 16 \mathrm{mg} / \\
\text { kg; } \\
\text { Median: } 2 \\
\text { Range: } 1-3 \\
\text { Thal: not reported } \\
\text { Len (not refractory): } \\
34 \% \text {. } \\
\text { Bort: not reported }\end{array}$ & $\begin{array}{l}\text { Phase 2 with } \\
\text { Daratumumab } 16 \\
\text { mg/kg; } \\
\text { >PR: } 88 \% \\
\text { VGPR: } 28 \% \\
\text { CR: } 25 \%\end{array}$ & $\begin{array}{l}\text { Phase } 2 \text { with } \\
\text { daratumumab } \\
16 \mathrm{mg} / \mathrm{kg} \\
\text { Not reported }\end{array}$ & $\begin{array}{l}\text { Phase } 2 \text { with } \\
\text { daratumumab } 16 \mathrm{mg} / \\
\mathrm{kg} ; \\
\text { IRR: } 56 \% \text {, mostly } \\
\text { grade } 1 / 2 \text { (grade } \\
3 \text { in } 6 \% \text { ) }\end{array}$ \\
\hline $\begin{array}{l}\text { NCT01998971 } \\
\text { Chari A, } \\
\text { et al26 }\end{array}$ & Phase $1 \mathrm{~b}$ & $\begin{array}{l}\text { daratumumab } \\
\text { pomalidomide } \\
\text { dexamethasone }\end{array}$ & $\begin{array}{l}\text { Daratumumab } 16 \mathrm{mg} / \mathrm{kg} \text { iv } \\
\text { weekly for cycles } 1-2 \text {, } \\
\text { every other week for } \\
\text { cycles } 3-6 \\
\text { monthly starting with } \\
\text { cycle } 7 \\
\text { Pom: } 4 \mathrm{mg} \text { po d1-21 } \\
\text { Dex: } 40 \mathrm{mg} \text { weekly } \\
\text { In } 28 \text { d cycles }\end{array}$ & 77 & $\begin{array}{l}\text { RRMM } \\
\text { Median: } 3.5 \\
\text { Range: } 2-10 \\
\text { Thal-refractory: not } \\
\text { reported: } \\
\text { Len-refractory: } 88 \% \\
\text { Bort-refractory: } 65 \% \\
\text { Carf-refractory: } 30 \% \\
\text { PI and IMID- } \\
\text { refractory: } 65 \%\end{array}$ & $\begin{array}{l}53 \text { patients with } \\
>1 \text { post-baseline } \\
\text { assessment; } \\
\geq \text { PR: } 58.5 \% \\
\text { VGPR: } 23 \% \\
\text { CR: } 8 \% \\
\text { Double-refractory } \\
\text { patients } \\
\text { (n=40); } \\
\geq \text { PR: } 57.5 \%\end{array}$ & $\begin{array}{l}\text { No results } \\
\text { provided }\end{array}$ & $\begin{array}{l}\text { IRR: } 61 \% \text {; } \\
\text { little additional } \\
\text { toxicity when } \\
\text { Daratumumab was } \\
\text { added to pom-dex }\end{array}$ \\
\hline
\end{tabular}

RRMM , relapsed/refractory multiple myeloma; NDMM, newly diagnosed multiple myeloma; bort, bortezomib; carf, carfilzomib; dex, dexamethasone; pom, pomalidomide; len, lenalidomide; PI, proteasome inhibitor; thal, thalidomide; CR, complete response; PD, progressive disease; PR, partial response; VGPR, very good partial response. SD, stable disease; TTE, time to events; ORR, overall response rate was defined as partial response or better; NE, not estimate; PFS, progression-free survival; OS, overall survival; IRR, infusion-related reaction;

antigen-binding domain from a $\mathrm{B}$ cell receptor that is fused to the intracellular domain of a CD3 T-cell receptor (CD3-zeta), have shown activity in CD-19 related disease [56]. Although $95 \%$ of MM patients do not express CD19 on their tumor cells, CAR T-cells have been used effectively to induce remission in MM patients. One way to improve the outcomes of CAR T-cell treatment in MM patients is to develop effective immunotherapies targeting antigens expressed by MM cells. A fitting target for CAR T-cell therapy of MM had not been previously identified because most proteins expressed on MM cells are also expressed on essential normal cells. Both B-cell maturation antigen (BCMA) and CS1 have been identified as promising immunotherapeutic targets in $\mathrm{MM}[57,58]$. BCMA is expressed in mature B cells and plasma cells and promotes the survival of long-lived plasma cells [59]. BCMA expression is high in most, if not all, MM cells. A wide range screening of normal human tissues by immunohistochemistry revealed no expression of BCMA except in lymphoid tissue, suggesting that an anti-BCMA CAR T-cell therapy will have favorable efficacy in MM [57].

At the ASH 2015 meeting, impressive results were reported by Dr. Kochenderfer regarding novel CAR T-cell therapy targeting BCMA [60]. This dose-escalating phase 1 trial enrolled a total of 12 heavily pretreated patients. Each patient received a single infusion of their modified $\mathrm{T}$ cells after first being administered cyclophosphamide $300 \mathrm{mg} / \mathrm{m}^{2}$ and fludarabine $30 \mathrm{mg} / \mathrm{m}^{2}$ for three days. Among the two patients who received the maximum dose, one patient showed a complete and durable remission. However, sings of cytokine release syndrome occurred, necessitating management.

\section{OTHER NOVEL AGENTS}

\section{Filanesib (kinesin spindle inhibitor)}

Filanesib (Arry-520) is a kinesin spindle protein inhibitor that arrests cells undergoing mitosis and promotes apoptosis [61]. In highly refractory MM patients, single agent Filanesib resulted in a $16 \%$ PR and when in combination with dexamethasone, the PR increased to $22 \%$. Filanesib in combination with low dose dexamethasone has shown a manageable safety profile [62]. The drug is also being tried in other combinations with PIs (bortezomib or carfilzomib). A phase I study in combination with bortezomib reported an ORR of $42 \%$ and the combination was found to be well-tolerated [63]. Shah et al. reported a $42 \%$ ORR ( $\geq$ PR) and $52 \%$ clinical benefit rate $(\geq$ MR) for the combination with carfilzomib in the phase 1 study [64] [53]. Zonder et al. reported an ORR of $30 \%$ for a combination with carfilzomib in 72 patients with at least 2 prior regimens with BTZ and IMiD. The most common hematologic toxicities included anemia, neutropenia and thrombocytopenia [65].

\section{Selinexor (SINE inhibitor)}

Selinexor (KPT-330) is a novel member of the selective inhibitors of nuclear export (SINE) class of compounds. KPT-330 has significant activity against hematological malignancies, especially those that are refractory to standard chemotherapeutic agents [66]. In a phase I dose escalation study (NCT01607892) conducted by $\mathrm{Chen}$ et al., $40 \%$ showed minimal response, $6.7 \%$ partial response and 33\% had stable disease among the 17 heavily pretreated relapsed or refractory MM patients. The most common side effects were anorexia, nausea, 
vomiting, diarrhea, thrombocytopenia and neutropenia. These side effects were well managed with supportive care [67]. A phase I study of selinexor combined with carfilzomib and dexamethasone to evaluate both efficacy and tolerance is currently underway (NCT02199665) $[68,69]$. The early results show a $75 \%$ PR without any unexpected toxicities in those refractory to carfilzomib, suggesting that this regimen overcomes carfilzomib resistance [70]. Also phase $1 / 2$ clinical trials in combination with dexamethasone, liposomal doxorubicin, pomalidomide/dexamethasone, or PIs/dexamethasone are ongoing, with promising interim results (NCT02336815, NCT02186834, or NCT02199665, respectively) [71].

In conclusion, 2015 has been an exciting year for relapsed/refractory $\mathrm{MM}$, with three drugs approved by U.S. FDA - namely ixazomib, elotuzumab and daratumumab. The first two drugs were approved for use with dexamethasone and lenalidomide in patients with one prior line of therapy. Therefore, now we have three options in the patients with one to three prior lines of treatment. Data have been reported on carfilzomib being combined with lenalidomide/dexamethasone and on ixazomib and elotuzumab being combined with lenalidomide/ dexamethasone. On the other hand, daratumumab was approved for use as a single agent for patients with double refractory disease or those who have had more than three lines of therapy.

It is difficult to predict which of these drugs will be a frontrunner in the future therapy of MM. The choice of optimal combination therapy can be made only after giving due consideration to various factors. These factors include (1) treatment-related factors: sensitivity and tolerability to prior treatments; (2) disease-related factors: disease presentation and cytogenetics; and (3) patientrelated factors: age, organ failure and comorbidities. Headto-head comparisons are required to explore the efficacy of these novel treatments in certain subgroups of patients. Based on the current data, we suggest that carfilzomib and ixazomib combinations may be utilized for people who require fairly rapid cytoreduction. Particular ixazomib combinations may be utilized for older patients because ixazomib is remarkably well tolerated, and elotuzumab may be an option that is suitable for slow biochemical relapses or patients who have other comorbidities because of elotuzumab's fairly decent safety profile. Daratumumab is a good choice for heavily treated or late relapse patients. Based on daratumumab's single-agent activity, it is also being brought early into the clinical setting.

Several trials are in progress with the goal of further improvement in clinical outcomes for our patients with MM. Thus, we believe that we are at the verge of another paradigm shift in the management of MM.

\section{FUNDING SUPPORT}

Steve and Nancy Fox Fund, MD Anderson Cancer
Centre, Houston, Texas, USA

\section{CONFLICTS OF INTEREST}

There is no conflict of interest that I should disclose, having read the above statement.

\section{DISCLOSURE}

Neither the submitted manuscript nor any similar manuscript, in whole or in part, other than an abstract, is under consideration, in press, published, or reported elsewhere.

\section{REFERENCES}

1. Siegel R, Naishadham D and Jemal A. Cancer statistics, 2013. CA: a cancer journal for clinicians. 2013; 63(1):1130.

2. Anderson $\mathrm{KC}$, Alsina $\mathrm{M}$, Atanackovic $\mathrm{D}$, Biermann JS, Chandler JC, Costello C, Djulbegovic B, Fung HC, Gasparetto C and Godby K. NCCN Guidelines Insights: Multiple Myeloma, Version 3.2016. Journal of the National Comprehensive Cancer Network. 2016; 14(4):389-400.

3. Vitry A, Mintzes B and Lipworth W. Access to new cancer medicines in Australia: dispelling the myths and informing a public debate. Journal of pharmaceutical policy and practice. 2016; 9(1):1.

4. Gentile M, Recchia AG, Mazzone C and Morabito F. Emerging biological insights and novel treatment strategies in multiple myeloma. Expert opinion on emerging drugs. 2012; 17(3):407-438.

5. Kumar SK, LaPlant B, Roy V, Reeder CB, Lacy MQ, Gertz MA, Laumann K, Thompson MA, Witzig TE, Buadi FK, Rivera CE, Mikhael JR, Bergsagel PL, Kapoor P, Hwa L, Fonseca R, et al. Phase 2 trial of ixazomib in patients with relapsed multiple myeloma not refractory to bortezomib. Blood Cancer J. 2015; 5:e338.

6. Murray MY, Auger MJ and Bowles KM. Overcoming bortezomib resistance in multiple myeloma. Biochem Soc Trans. 2014; 42(4):804-808.

7. Steele JM. Carfilzomib: A new proteasome inhibitor for relapsed or refractory multiple myeloma. J Oncol Pharm Pract. 2013; 19(4):348-354.

8. Buac D, Shen M, Schmitt S, Kona FR, Deshmukh R, Zhang Z, Neslund-Dudas C, Mitra B and Dou QP. From bortezomib to other inhibitors of the proteasome and beyond. Curr Pharm Des. 2013; 19(22):4025-4038.

9. Muz B, Ghazarian RN, Ou M, Luderer MJ, Kusdono HD and Azab AK. Spotlight on ixazomib: potential in the treatment of multiple myeloma. Drug Des Devel Ther. 2016; 10:217-226.

10. Moreau P, Masszi T, Grzasko N, Bahlis NJ, Hansson M, Pour L, Sandhu I, Peter G, Baker BW, Jackson S, 
Stoppa AM, Simpson DR and Gimsing P. Ixazomib, an Investigational Oral Proteasome Inhibitor (PI), in Combination with Lenalidomide and Dexamethasone (IRd), Significantly Extends Progression-Free Survival (PFS) for Patients (Pts) with Relapsed and/or Refractory Multiple Myeloma (RRMM): The Phase 3 TourmalineMM1 Study (NCT01564537). Blood. ;727. 2015; 126 SRC - GoogleScholar.

11. Kumar SK, Berdeja JG, Niesvizky R, Lonial S, Laubach JP, Hamadani M, Stewart AK, Hari P, Roy V, Vescio R, Kaufman JL, Berg D and Liao E. Safety and tolerability of ixazomib, an oral proteasome inhibitor, in combination with lenalidomide and dexamethasone in patients with previously untreated multiple myeloma: an open-label phase 1/2 study. The Lancet Oncology. 2014; 15:1503-1512.

12. Dimopoulos MA, Grosicki S, Jedrzejczak WW, Nahi H, Gruber A, Hansson M, Byrne C, Labotka R, Hui AM, Teng ZY and Grzasko N. Randomized Phase 2 Study of the All-Oral Combination of Investigational Proteasome Inhibitor (PI) Ixazomib Plus Cyclophosphamide and Low-Dose Dexamethasone (ICd) in Patients (Pts) with Newly Diagnosed Multiple Myeloma (NDMM) Who Are Transplant-Ineligible (NCT0070). Blood. ;26. 2015; 126 SRC - GoogleScholar.

13. Richardson PG, Baz R, Wang M, Jakubowiak AJ, Laubach JP, Harvey RD, Talpaz M, Berg D, Liu G, Yu J, Gupta N, Di Bacco A, Hui AM and Lonial S. Phase 1 study of twice-weekly ixazomib, an oral proteasome inhibitor, in relapsed/refractory multiple myeloma patients. Blood. 2014; 124(7):1038-1046.

14. van Lokhorst HM and de Donk NW. New developments in the management and treatment of newly diagnosed and relapsed/refractory multiple myeloma patients. Expert opinion on pharmacotherapy. 2013; 14:1569-1573.

15. Kumar SK, Lee JH, Lahuerta JJ, Morgan G, Richardson PG, Crowley J, Haessler J, Feather J, Hoering A, Moreau $\mathrm{P}$, LeLeu $\mathrm{X}$, Hulin $\mathrm{C}$ and Klein SK. International Myeloma Working Group. Risk of progression and survival in multiple myeloma relapsing after therapy with IMiDs and bortezomib a multicenter international myeloma working group study Leukemia. 2012; 26 SRC GoogleScholar:149-157.

16. van de Donk NW, Moreau P, Plesner T, Palumbo A, Gay F, Laubach JP, Malavasi F, Avet-Loiseau H, Mateos MV, Sonneveld P, Lokhorst HM and Richardson PG. Clinical efficacy and management of monoclonal antibodies targeting CD38 and SLAMF7 in multiple myeloma. Blood. 2016; 127(6):681-695.

17. Bergsagel PL. Where we were, where we are, where we are going: progress in multiple myeloma. American Society of Clinical Oncology educational book / ASCO American Society of Clinical Oncology Meeting. 2014:199-203

SRC - GoogleScholar.

18. Dimopoulos MA, Richardson PG, Moreau P and Anderson KC. Current treatment landscape for relapsed and/or refractory multiple myeloma. Nature reviews Clinical oncology. 2015; 12 SRC - GoogleScholar:42-54.

19. van de Donk NW, Kamps S, Mutis T and Lokhorst HM. Monoclonal antibody-based therapy as a new treatment strategy in multiple myeloma. Leukemia. 2012; 26(2):199213.

20. Raje N, Longo DL, N. and J. Monoclonal Antibodies in Multiple Myeloma Come of Age. 2015; 373 SRC GoogleScholar:1264-1266.

21. Lonial S, Durie B, Palumbo A and San-Miguel J. Monoclonal antibodies in the treatment of multiple myeloma: current status and future perspectives. Leukemia. 2016; 30:526-535.

22. van de Donk NW, Janmaat ML, Mutis T, Lammerts van Bueren JJ, Ahmadi T, Sasser AK, Lokhorst HM and Parren PW. Monoclonal antibodies targeting CD38 in hematological malignancies and beyond. Immunol Rev. 2016; 270(1):95-112.

23. Weers M, Tai Y, Veer M, Bakker JM, Vink T, Jacobs DC, Oomen LA, Peipp M, Valerius T, Slootstra JW, Mutis T, Bleeker WK, Anderson KC and J. De Van Der Daratumumab, a novel therapeutic human CD38 monoclonal antibody, induces killing of multiple myeloma and other hematological tumors. 2011; 186 SRC GoogleScholar:1840-1848.

24. Overdijk MB, Verploegen S, van Egmond M, van Bueren JJ, Mutis T, Groen RW, Breij E, Martens AC, Bleeker WK and Parren PW. B"ogels M, Lammerts Antibodymediated phagocytosis contributes to the anti-tumor activity of the therapeutic antibody daratumumab in lymphoma and multiple myeloma. MAbs. 2015; 7 SRC GoogleScholar:311-321.

25. van der Veer MS, de Weers M, van Kessel B, Bakker JM, Wittebol S, Parren PW, Lokhorst HM and Mutis T. The therapeutic human CD38 antibody daratumumab improves the anti-myeloma effect of newly emerging multi-drug therapies. Blood Cancer J. 2011; 1(10):e41.

26. Jansen JH, Boross P, Overdijk MB, Jeroen J, van Bueren L, Parren P and Leusen J. Marco Daratumumab, a human CD38 antibody induces apoptosis of myeloma tumor cells via fc receptor-mediated crosslinking. Blood 2974. 2012; 120 SRC - GoogleScholar.

27. Lonial S, Weiss BM, Usmani SZ, Singhal S, Chari A, Bahlis NJ, Belch A, Krishnan A, Vescio RA, Mateos MV, Mazumder A, Orlowski RZ and Sutherland HJ. Daratumumab monotherapy in patients with treatmentrefractory multiple myeloma (SIRIUS): an open-label, randomised, phase 2 trial. Lancet. 2016; 387:1551-1560.

28. Horsham PA. (2016). Darzalex package insert.

29. Plesner T, Arkenau HT, Gimsing P, Krejcik J, Lemech C, Minnema MC, Lassen U, Laubach JP, Palumbo A, Lisby S, Basse L, Wang JP and Sasser AK. Daratumumab in Combination with Lenalidomide and Dexamethasone in Patients with Relapsed or Relapsed and Refractory Multiple 
Myeloma: Updated Results of a Phase 1/2 Study (GEN503). Blood.; 507. 2015; 126 SRC - GoogleScholar.

30. Usmani S, Weiss B, Bahlis NJ, Belch A, Lonial S, Lokhorst H, Voorhees PM, Richardson PG, Sasser AK, Axel A, Feng HB, Uhlar C and Wang JP. Clinical Efficacy of Daratumumab Monotherapy in Patients with Heavily Pretreated Relapsed or Refractory Multiple Myeloma. Blood 29. 2015; 126 SRC - GoogleScholar.

31. Chari A, Lonial S, Suvannasankha A, Fay JW, Arnulf B, Ifthikharuddin JJ, Qin X, Masterson T, Nottage K, Schecter JM, Ahmadi T, Weiss B and Krishnan A. OpenLabel, Multicenter, Phase 1b Study of Daratumumab in Combination with Pomalidomide and Dexamethasone in Patients with at Least 2 Lines of Prior Therapy and Relapsed or Relapsed and Refractory Multiple Myeloma. Blood 508. 2015; 126 SRC - GoogleScholar.

32. His ED, Steinle R, Balasa B, Szmania S, Draksharapu A, Shum BP, Huseni M, Powers D, Nanisetti A, Zhang Y, Rice AG, van Abbema A and Wong M. (2008). CS1, a potential new therapeutic antibody target for the treatment of multiple myeloma.

33. Lonial S, Dimopoulos M, Palumbo A, White D, Grosicki S, Spicka I, Walter-Croneck A, Moreau P, Mateos MV, Magen H, Belch A, Reece D, Beksac M, Spencer A, Oakervee H, Orlowski RZ, et al. Elotuzumab Therapy for Relapsed or Refractory Multiple Myeloma. The New England journal of medicine. 2015; 373(7):621-631.

34. Collins SM, Bakan CE, Swartzel GD, Hofmeister CC, Efebera YA, Kwon H, Starling GC, Ciarlariello D, Bhaskar S, Briercheck EL, Hughes T, Yu J and Rice A. Elotuzumab directly enhances NK cell cytotoxicity against myeloma via CS1 ligation: evidence for augmented NK cell function complementing ADCC. Cancer Immunol Immunother. 2013; 62:1841-1849.

35. Guo H, Cruz-Munoz M, Wu N, Robbins $M$ and Veillette A. E, Immune cell inhibition by SLAMF7 is mediated by a mechanism requiring src kinases, CD45, and SHIP-1 that is defective in multiple myeloma cells. Mol Cell Biol. 2015; 35:41-51.

36. Quintero LA, Roncagalli R, Guo H, Latour S, Davidson D, Veillette A and J. Pérez- EAT-2, a SAP-like adaptor, controls NKcell activation through phospholipase $\mathrm{C} \gamma$, $\mathrm{Ca}++$, and Erk, leading to granule polarization. Med. 2014; 211 SRC - GoogleScholar:727-742.

37. Tai YT, Dillon M, Song W, Leiba M, Li XF, Burger P, Lee AI, Podar K, Hideshima T, Rice AG, van Abbema A, Jesaitis L and Caras I. Anti-CS1 humanized monoclonal antibody HuLuc63 inhibits myeloma cell adhesion and induces antibody-dependent cellular cytotoxicity in the bone marrow milieu. Blood. 2008; 112 SRC GoogleScholar:1329-1337.

38. Rajkumar SV and Kumar S. Multiple Myeloma: Diagnosis and Treatment. Mayo Clin Proc. 2016; 91(1):101-119.

39. Starr P. Elotuzumab, first-in-class monoclonal antibody immunotherapy, improves outcomes in patients with multiple myeloma. American health \& drug benefits. 2015; 8(Spec Issue): 17 .

40. Dimopoulos MA, Lonial S, White D, Palumbo A, Miguel JS, Shpilberg O, Anderson KC, Grosicki S, Spicka I, Walter-Croneck A, Magen-Nativ H, Mateos MV, A. and Open-Label R. MoreauP, Eloquent-2 Update: 3, of Elotuzumab in Combination with Lenalidomide/ Dexamethasone in Patients with Relapsed/Refractory Multiple Myeloma-3-Year Safety and Efficacy Follow-up. Blood 28. 2015; 126 SRC - GoogleScholar.

41. Palumbo A, Offidani M, Rubia J, Garderet L, Laribi K, Bosi A, Marasca R, Laubach JP, Mohrbacher A, Carella AM, Singhal AK and Lynch M. Pégourie B, De La Elotuzumab Plus Bortezomib and Dexamethasone Versus Bortezomib and Dexamethasone in Patients with Relapsed/Refractory Multiple Myeloma: 2-Year Follow-up. Blood 510. 2015; 126 SRC - GoogleScholar.

42. Lonial S, Dimopoulos M, Palumbo A, White D, Grosicki S, Spicka I, Walter-Croneck A, Moreau P, Mateos MV, Magen H, Belch A, Reece D, Beksac M, J. and N. ELOQUENT-2 Investigators. Elotuzumab Therapy for Relapsed or Refractory Multiple Myeloma. 2015; 373 SRC - GoogleScholar:621-631.

43. Keir ME, Butte MJ, Freeman GJ and Sharpe AH. PD-1 and its ligands in tolerance and immunity. Annu Rev Immunol. 2008; 26:677-704.

44. Ishida Y, Agata Y, Shibahara K and Honjo T. Induced expression of PD-1, a novelmember of the immunoglobulin gene superfamily, upon programmed cell death. EMBO J. 1992; 11:3887-3895.

45. Seo SK, Seo HM, Jeong HY, Choi IW, Park YM, Yagita H, Chen L and Choi IH. Co-inhibitory role of T-cell-associated and B7-DC in the T-cell immune response. Immunol Lett 222228. 2006; 102 SRC - GoogleScholar:B7-H1.

46. Okazaki T, The PD and Honjo T. 1-PD-L pathway in immunological tolerance. Trends Immunol. 2006; 27:195201.

47. Ahmadzadeh M, Johnson LA, Heemskerk B, Wunderlich JR, Dudley ME, White DE and Rosenberg SA. Tumor antigen-specific CD8 T cells infiltrating the tumor express high levels of PD-1 and are functionally impaired. Blood. 2009; 114 SRC - GoogleScholar:1537-1544.

48. Iwai $\mathrm{Y}$, Ishida $\mathrm{M}$, Tanaka $\mathrm{Y}$, Okazaki $\mathrm{T}$, Honjo $\mathrm{T}$, Minato $\mathrm{N}$ and Sci USA. Involvement of PD-L1 on tumor cells in the escape from host immune system and tumor immunotherapy by PD-L1 blockade. Proc Natl Acad. 2002; 99 SRC - GoogleScholar:12293-12297.

49. Brahmer JR, Drake CG, Wollner I, Powderly JD, Picus J, Sharfman WH, Stankevich E, Pons A, Salay TM, McMiller TL, Gilson MM, Wang C, Selby M, Phase I and J. study of single-agent anti-programmed death-1 (MDX1106) in refractory solid tumors: safety, clinical activity, pharmacodynamics, and immunologic correlates. Oncol. 2010; 28 SRC - GoogleScholar:3167-3175. 
50. Francisco LM, Salinas VH, Brown KE, Vanguri VK, Freeman GJ, Kuchroo VK, Sharpe AH and J. PD-L1 regulates the development, maintenance, and function of induced regulatory T cells. Med. 2009; 206 SRC GoogleScholar:3015-3029.

51. Terme M, Ullrich E, Aymeric L, Meinhardt K, Desbois M, Delahaye N, Viaud S, Ryffel B, Yagita H, Kaplanski G, Blondel A, Kato M and Schultze JL. Prévost- IL-18 induces PD-1-dependent immunosuppression in cancer. Cancer Res. 2011; 71:5393-5399.

52. Bryan LJ and Gordon LI. Releasing the Brake on the Immune System: The PD-1 Strategy for Hematologic Malignancies. Oncology (Williston Park, NY). 2015; 29(6):431-439.

53. Lesokhin AM, Ansell SM, Armand P, Scott EC, Halwani A, Gutierrez M, Millenson MM, Cohen AD, Schuster SJ, Lebovic D, Dhodapkar MV, Avigan D and Chapuy B. Preliminary results of a phase I study of nivolumab(BMS-936558) in patients with relapsed or refractory lymphoid malignancies. Blood 289. 2014; 124 SRC - GoogleScholar.

54. Miguel J, Mateos MV, Shah JJ, Ocio EM, RodriguezOtero P, Reece D, Munshi NC, Avigan D, Ge Y, Balakumaran A, Marinello P, Orlowski RZ and Siegel D. San Pembrolizumab in Combination with Lenalidomide and Low-Dose Dexamethasone for Relapsed/Refractory Multiple Myeloma (RRMM): Keynote-023.Blood.; 505. 2015; 126 SRC - GoogleScholar.

55. Badros AZ, Kocoglu MH, Ma N, Rapoport AP, Lederer E, Philip S, Lesho P, Dell C, Hardy NM, Yared J, Goloubeva O, Anti PD, Singh Z, I and A. of 1 Antibody Pembrolizumab, Pomalidomide and Dexamethasone in Patients with Relapsed/Refractory Multiple Myeloma (RRMM). Blood.; 506. 2015; 126 SRC - GoogleScholar.

56. Kocoglu M and Badros A. The Role of Immunotherapy in Multiple Myeloma. Pharmaceuticals (Basel). 2016; 9(1).

57. Carpenter RO, Evbuomwan MO, Pittaluga S, Rose JJ, Raffeld M, Yang S, Gress RE, Hakim FT, Kochenderfer JN and Adoptive T. B-cell Maturation Antigen Is a Promising Target for cell Therapy of Multiple Myeloma. Clinical cancer research. 2013; 19 SRC - GoogleScholar:2048-2060.

58. Chu J, He S, Deng Y, Zhang J, Peng Y, Hughes T, Yi L, Kwon CH, Wang QE, Devine SM, He X, Bai XF, Hofmeister CC and Yu J. Genetic modification of $\mathrm{T}$ cells redirected toward CS1 enhances eradication of myeloma cells. Clinical cancer research. 2014; 20:3989-4000.

59. Gill S and June CH. Going viral: chimeric antigen receptor T-cell therapy for hematological malignancies. Immunol Rev. 2015; 263(1):68-89.

60. Ali SA, Shi V, Wang M, Stroncek D, Maric I, Brudno JN, Stetler-Stevenson M, Rose JJ, Feldman S, Hansen B, Hakim FT, Gress RE, Kochenderfer JN and T. Remissions of Multiple Myeloma during a First-in-Humans Clinical Trial of Expressing an Anti-B-Cell Maturation Antigen Chimeric Antigen Receptor. BloodLBA1. 2015; 126 SRC -
GoogleScholar.

61. Ocio EM, Richardson PG, Rajkumar SV, Palumbo A, Mateos MV, Orlowski R, Kumar S, Usmani S, Roodman D, Niesvizky R, Einsele H, Anderson KC, Dimopoulos MA, Avet-Loiseau H, Mellqvist UH, Turesson I, et al. New drugs and novel mechanisms of action in multiple myeloma in 2013: a report from the International Myeloma Working Group (IMWG). Leukemia. 2014; 28(3):525-542.

62. Shah JJ, Zonder JA, Cohen A, Bensinger W, Kaufman JL, Orlowski RZ and H. AS. The novel KSP inhibitor ARRY520 is active both with and without low-dosedexamethasone in patients with multiple myeloma refractory to bortezomib andlenalidomide: results from a phase 2 study. Meet Abstr 449. 2012; 120 SRC - GoogleScholar.

63. Chari A, Htut M, Zonder JA and H. AS. A phase I study of ARRY-520 (filanesib) with bortezomib in relapsed or refractory multiple myeloma. Meeting Poster. 1938.

64. Shah JJ, Feng L, Thomas SK, Weber D, Wang M and H. AS. Phase 1 Study of the Novel Kinesin Spindle Protein Inhibitor Filanesib + Carfilzomib in Patients with Relapsed and/or Refractory Multiple Myeloma (RRMM).Meeting .Abstr376.orBlood. ;376. 2015; 126 SRC - GoogleScholar.

65. Zonder JA, Usmani S, Scott ES, Hofmeister CC and H. AS. Phase 2 Study of Carfilzomib (CFZ) with or without Filanesib (FIL) in Patients with Advanced Multiple Myeloma (MM). Meeting .Abstr 728. or Blood 728. 2015; 126 SRC - GoogleScholar.

66. Ishizawa J, Kojima K, Tabe Y, N. and Andreeff M. Hail, Expression, function, and targeting of the nuclear exporter chromosomeregion maintenance 1 (CRM1) protein. Pharmacology \& Therapeutics. 2015; 153 SRC GoogleScholar:25-35.

67. Chen CI, Gutierrez M, Brown P and H. AS. deNully Antitumor activity of selinexor (KPT-330), a firstinclass oral selective inhibitor of nuclear export (SINE) XPO1/CRM1 antagonist in patients with relapsed/refractory multiple myeloma (MM) or Waldenstrom'smacroglobulinemia (WM). Meeting; Abstr. 1942.

68. Ashjian E and Redic K. Multiple myeloma: Updates for pharmacists in the treatment of relapsed and refractory disease. J Oncol Pharm Pract. 2016; 22(2):289-302.

69. M. NL. University of Chicago. Selinexor carfilzomib and dexamethasone in treating patients with relapsed or refractory multiple myeloma SINE ClinicalTrialsgov Internet National Library of Medicine US httpsclinicaltrialsgovet2showNCT0265 0265. 1996.

70. Jakubowiak A, Jasielec J, Rosenbaum CA, Zonder JA, Cole CE, Chari A, Nam J, Stephens LA, Rosebeck S, Rashal T, McDonnell K, Uribe R and Youssoufian H. Blood. ; 4223. 2015; 126 SRC - GoogleScholar.

71. Bianchi G, Richardson PG and Anderson KC. Promising therapies in multiple myeloma. Blood. 2015; 126:300-310. 